\title{
Strategi Pengembangan Potensi Wisata Bahari Pulau Tunda, Kecamatan Tirtayasa, Kabupaten Serang, Provinsi Banten
}

Bangga Prameswara a,1, Ida Bagus Suryawan a,2

'banggaprameswara@yahoo.com 2idabagussuryawan@unud.ac.id

a Program Studi Sarjana Destinasi Pariwisata, Fakultas Pariwisata, Universitas Udayana, Jl. Dr. R. Goris, Denpasar, Bali 80232 Indonesia

\begin{abstract}
The study aims to determine Development Strategy the potency of the Tunda Island as a tourist attraction in the Serang Regency, Banten Province. How the development of appropriate strategy to overcome obstacles in the development of Tunda Island Coast region as a Marine Tourism attraction in Serang Regency, Banten Province.

This study was conducted to determine the Tunda Island as a marine tourism destination Serang Regency were reviewed by using SWOT analysis. This study uses quialitative research methods with data collection techniques such as interviews, observation, and documentation studies.

The results of the research carried out that Pulau Tunda as a marine tourism attraction in Serang Regency has the power in the form of underwater natural potential that is different from other islands in Serang Regency, besides Tunda Island has a considerable opportunity for increasing tourism needs and locations that tend to strategic. However, Pulau Tunda has weaknesses in the quality of human resources as well as low tourism support facilities and garbage that has not been managed properly. Meanwhile the threat faced by Tunda Island is currently the operation of sand miners and the lack of attention from the local government.
\end{abstract}

Keywords: Development Strategy, Tunda Island, Marine Tourism

\section{PENDAHULUAN}

Indonesia merupakan Negara dengan pulau-pulau sumber daya alamnya sangat melimpah. Menurut (Fandeli, 1995) dimana daya tarik wisata berasal dari potensi yang merupakan sumber daya yang dimiliki. Beraneka ragam dan banyaknya potensi wisata alam yang dimiliki Indonesia dengan laut yang luas dan pulau-pulau sebagai Negara kepulauan. Wisata Bahari merupakan salah satu jenis pariwisata yang dimiliki Indonesia.

Dengan dikembangkannya pariwisata bahari harus tersedia syarat-syarat tersedianya daya tarik wisata dan objek wisata. Cara hidup (the way of life), benda buatan manusia (man made supply) dan benda-benda yang berasal dari alam (natural amenities) merupakan atraksi dan objek wisata (Yoeti, 1996). Provinsi Banten mengeluarkan rencana induk pengembangan pariwisata pada Peraturan Daerah tahun 2005 nomor 9, Provinsi Banten mengembangkan wisata terbagi menjadi 3 bagian wilayah pengembangan pariwisata. Pertama, wilayah pengembangan pariwisata A dengan satuan kawasan pengembangan pariwisata melingkupi Tanggerang, Pantai Utara dan Serang. Kedua, pengembangan wilayah pariwisata B dengan satuan kawasan pengembangan pariwisata melingkupi Cilegon, Pantai Barat, dan Ujung Kulon. Ketiga, wilayah pengembangan pariwisata $\mathrm{C}$ dengan satuan kawasan pengembangan pariwisata melingkupi Banten Tengah dan Pantai Selatan.Saat ini, salah satu prioritas pengembangan kepariwisataan di Provinsi Banten terdapat pada wilayah Kabupaten Serang yang sebagian besar berupa pengembangan pariwisata berjenis pariwisata bahari.

Pulau Tunda menyimpan keindahan bawah laut yang berpotensi dikembangkan menjadi sebuah daya tarik wisata bahari. Di sekeliling pulau ditemukan Fringing Reef ataupun karang tepi. Pada kedaleman 1-10 meter karang tersebut hidup. Kawasan Pulau Tunda sebelah timur merupakan daerah dengan arus yang besar sehingga sering digunakan untuk diving dan juga snorkeling. Selain itu, daerah timur juga dapat ditemukan clown fish dan binatang laut lainnya. Daerah timur pun memiliki visibility (Jarak Pandang) yang cukup baik yaitu sekitar 10 meter. Daerah Utara pulau dihiasi beragam karang dengan visibility sekitar 12 meter. Pada bagian Utara ini belum banyak tersentuh oleh aktifitas manusia sehingga karangnya pun masih alami. 
Meskipun tidak seperti di Kilauan yang dapat setiap hari melihat atraksi lumba-lumba, namun pada waktu-waktu tertentu di Pulau Tunda pun dapat ditemukan atraksi ikan lumba-lumba, Hal ini dikarenakan Pulau Tunda menjadi jalur migrasi lumba-lumba.

Pulau Tunda memiliki potensi yang cukup baik yakni dari arah darat ke laut berturut-turut terdapat vegetasi terumbu karang, hutan bakau dan padang lamun. Produktivitas yang tinggi (subur) dan sempurna dipunyai ekosistem tersebut, juga memberikan keindahan alam yang luar biasa, mengingat kunjungan wisata di Banten tidak hanya difokuskan dan tertuju pada daerah yang sudah sering dikunjungi, maka Pulau Tunda dapat dioptimalkan pengembangan dan pengelolaannya sebagai peluang yang lumayan besar, sehingga keberadaan Pulau Tunda lebih dapat diketahui keberadaannya oleh wisatawan lokal maupun interlokal yang berkunjung ke Banten. Namun kendala yang dihadapi dalam pengembangan potensi wisata bahari diperlukan strategi yang dapat memberikan solusi yang baik sehingga dalam penelitian ini untuk mengembangkan potensi tersebut maka untuk meningkatkan kesadaran pada masyarakat dan berdasar pada kelestarian alam berlandaskan pada Analisis SWOT (Strenght, Weakness, Opportunities, and Threat) sebagai manfaat keberadaan pariwisata di Kabupaten Serang, Kecamatan Tirtayasa, Desa Wargasara, tepatnya di Pulau Tunda.

Berdasarkan uraian diatas maka rumusan masalah artikel ini adalah apa potensi wisata yang dimiliki Pulau Tunda dan bagaimana strategi pengembangan potensi kawasan Pulau Tunda di Banten sebagai kawasan wisata bahari di Serang. Artikel ini bertujuan untuk memperoleh potensi maupun strategi pengembangan potensi kawasan Pulau Tunda sebagai daya tarik wisata bahari di Kabupaten Serang.

\section{TINJAUAN PUSTAKA}

\subsection{Telaah Penelitian Sebelumnya}

Jurnal Marhaeni (2001) berjudul "Strategy mengembangkan Objek wisata surfing sebagai Potensi di Pantai Suluban Desa Pecatu, Kabupaten Badung, Kecamatan
Kuta Selatan". Peneliti disini menguraikan tentang pengelolaan potensi yang dimiliki oleh daya tarik wisata Pantai Suluban dengan mengandalkan keindahan alam beserta besarnya ombak dalam pengembangan Pantai.

Jurnal lain penelitian yang berlokasi di Kabupaten Klungkung, Kecamatan Nusa Penida, Desa Sakti, tentang Strategy mengembangkan Potensi Wisata Bahari di Pantai Crystal Bay dari I Gede Anom Sastrawan (2014). Penelitian ini menguraikan tentang menjaga kelestarian dan mengoptimalkan potensi dalam pemanfaatannya di Pantai Crystal Bay sebagai daya tarik wisata bahari dalam strategi pengembangannya.

\subsection{Analisis Teori dan Landasan Konsep}

Berikut adalah konsep yang dipakai pada artikel ini, adalah :

1. Konsep Pariwisata

sejumlah aktivitas yang berhubungan dengan lalu lintas di suatu Negara yang dilalui oleh orang-orang asing untuk masuk berkaitan dengan perekonomian sebagai pemanfaatan pariwisata. (Schulard dalam Yoeti, 1996:114).

2. Konsep Pengelolaan

Menurut (Moekijat, 2000:1) pengawasan, penggerakan, pengorganisasian, perencanaan menggunakan manusia maupun sumber lain untuk menentukan juga mencapai tujuan tertentu disebut pengelolaan.

3. Konsep Strategi Pengembangan

Suatu daya taraik wisata dan kondisi kepariwisataan yang ditingkatkan. Diperbaiki, dan dimajukan oleh suatu strategi sehingga dapat memberikan masyarakat sekitar maupun pemerintah manfaat dan dikunjungi oleh wisatawan disebut strategi pengembangan. (Paturusi, 2001)

\section{Konsep Potensi}

Menurut (Yoeti, 1983) makna potensi adalah objek wisata yang berasal dari daya tarik yang dikembangkan dari sebuah potensi disebut potensi wisata, sehingga wisatawan mau berkunjung ke tempat tersebut untuk tujuan berwisata. Jadi dalam penelitian ini potensi yang 
dapat dijadikan sebuah daya tarik wisata. Pengertian potensi tersebut sudah termasuk potensi fisik alami, potensi fisik buatan maupun non fisik kebudayaan.

5. Konsep Daya Tarik Wisata

Menurut (UU Replubik Indonesia Nomor 10, 2009) semua yang memiliki nilai, keindahan maupun keunikan seperti berasal dari buatan manusia, kebudayaan, ataupun alam yang dijadikan tujuan dan sasaran para wisatawan.

6. Konsep Pengembangan Wisata Bahari

Wisata bahari tidak perlu pembuatan sarana maupun prasarana karena pada dasarnya wisatawan yang datang menginginkan hal yang berbau alami daya tarik wisatanya. Adapun aspek yang harus ada adalah sumber daya manusia yang siap, komunikasi yang bagus, originalitas buatan maupun alami, aksesbilitas yang baik, konservasi yang lahkahnya sudah terstruktur. (Prasiasa dan Hermawan, 2012)

7. Konsep Pariwisata Bahari

(Fandeli, 1995) mengatakan fisiografi di bawah air, rekreasi pantai, memancing, berjemur, selam, renang, dan snorkeling merupakan wisata yang disebut Wisata Bahari.

\section{METODE PENELITIAN}

Observasi ini dilaksanakan di Pulau Tunda, Provinsi Banten, Kabupaten Serang, Kecamatan Tirtayasa. Ruang lingkup dalam artikel ini menjadikan potensi nonfisik maupun fisik yang berada pada Pulau Tunda dan menganalisis strategi yang tepat dalam megembangkan potensi wisata bahari Pulau Tunda sebagai daya tarik wisata. Dalam artikel ini menggunakan data kualitatif (Sugiarto dan Kusmayadi, 2000), dan kuantitatif (Sugiarto dan Kusmayadi, 2000). Data primer dan juga data sekunder (Moleong, 2005). Observasi yang digunakan dalam teknik pengumpulan data (Kusmayadi, 2000), wawancara secara mendalam (Kusmayadi, 2000) juga dokumentasi (Sugiyono, 2009). Purposive Sampling untuk mengetahui informan (Muhktar, 2013). (Sugiyono, 2009) mengatakan analisis deskriptif kualitatif adalah teknik dalam penelitian ini yang berasal dari catatan lapangan, hasil wawancara. Dan hal lainnya secara sistematis agar mudah dimengerti dan diberitahukan kepada orang lain. Menurut
(Rangkuti, 2002) dengan melalui analisis SWOT dapat mengkaji potensi yang dipunyai Pulau Tunda sebagai daerah tujuan wisata bahari.

\section{HASIL DAN PEMBAHASAN \\ 4.1 Potensi Fisik Alami}

a. Mangrove yaitu hutan bakau yang hidup di air payau dan dipengaruhi pasang juga surut laut. Wilayah pesisir Pulau Tunda mempunyai ekoregion yang sempurna seringkali terdapat ekosistem hutan mangrove. Ekosistem hutan bakau adalah suatu ekosistem yang penting untuk menjaga stabilitas ekosistem tepi laut. Kegiatan kehutanan yang mungkin dikembangkan di wilayah pesisir meliputi pemanfaatan hutan mangrove yang disesuaikan dengan fungsi dan peruntukannya.

b. Pulau Tunda yang merupakan daerah pulau yang memiliki ekosistem dengan produktifitas tinggi salah satunya Padang Lamun. Padang Lamun adalah vegetasi tanaman bunga yang dapat hidup di air asin. Padang lamun adalah vegetasi dari tumbuhan bunga yang hidup semourna di laut yang dangkal. Ekosistem tumbuhan lamun umumnya berada pada wilayah pantai dengan arus dan gelombang yang relative tenang dan bersumbstrat dasar pasir halus hingga pasir berlumpur. Padang lamun, selain memiliki fungsi ekologis yang tidak jauh berbeda dengan ekosistem mangrove, dan memiliki nilai manfaat yang cukup tinggi bagi kehidupan masyarakat pesisir, terutama nelayan yang matapencaharian utamanya mencari sumber daya ikan. Secara ekologis tumbuhan padang lamun berperan sangat penting bagi daerah pesisir.

c. Laguna merupakan daerah perairan yang relatif dangkal dan sepi, terletak di lingkungan pesisir dan memiliki akses ke laut namun terpisah dari kondisi kelautan yang terbuka oleh penghalang. Hambatannya bisa berupa fitur yang berbentuk sandy atau shingly wavebuilt (seperti gundukan pasir atau pulau penghalang) atau mungkin juga terumbu karang. Dengan demikian, ada dua jenis laguna utama: Hamparan air yang memanjang atau tidak beraturan yang berada di antara pulau-pulau penghalang pesisir dan garis 
pantai dan hamparan air melingkar atau tidak teratur yang dikelilingi oleh terumbu karang atol atau dilindungi oleh terumbu karang penghalang dari aksi gelombang langsung kedalaman laguna dijaga pada tingkat yang moderat akibat sedimentasi dan ini mengkompensasi penurunan yang biasanya terjadi pada pembentukan terumbu karang. Karena terumbu adalah struktur organik, endapan laguna mengandung banyak bahan berkapur. Perairan yang terlindung mendukung ekosistem yang sangat produktif pada biota yang khas.

d. Paling menarik dari Pulau Tunda ialah keberadaan underwater great walls yaitu tembok-tembok karang yang berbidang vertical dari atas sampai bawah. Underwater great walls sebagai sumber hidup bagi biota laut di lingkungan sekitar perairan Pulo Tunda. Tingginya mencapai 10-15 meter dapat ditemui di kedalaman 15-25 meter dan berfungsi sebagai tempat tinggal biota laut yang dapat kita lihat adalah ikan nemo badut, ikan nemo kuning, ikan remora, ikan butterfly fish, ikan damsel, ikan sergeant fish dan ikan batfish. Tidak hanya memberikan pesona alam bawah laut pulau, karang ini berperan sebagai tempat mencari makan ikan-ikan tersebut.

e. Jenis ikan karang di Pulau Tunda pun beragam dan didominasi oleh ikan famili pomacentridae, sementara jenis ikan lainnya berasal dari Famili Caesionidea, Famili Labridea, Famili Apogenidea, Famili Chaetodontidea, Famili Nemipteridea, Famili Holoecentridea, Famili Scaridea, dan Famili Siganidea. Berdasarkan kajian yang dilakukan DKPESDM (Dinas Kelautan, Perikanan, Energi dan Sumberdaya Mineral) pada tahun 2015 bahwa keanekaragman ikan pada setiap spot tidak didominasi oleh salah satu jenis ikan tetapi terjadi secara seimbang.

\subsection{Potensi Fisik Buatan}

a. Dermaga Galau merupakan dermaga yang berbentuk seperti jembatan yang terbuat dari kayu dengan panjang jembatan ini sampai 20 meter karena ketidaktuntasan pemerintah dalam membangun jembatan ini. Pembangunan ini bertujuan agar para pengunjung bisa langsung turun dari jembatan ke tengah laut. Karena keunikan bentuk yang dibuat di atas permukaan laut ditambah mitosmitos yang dibuat masyarakat local menjadikan jembatan ini disukai dan dibicarakan oleh para pengunjung atau wisatawan yang datang.

b. Penginapan yang terdapat di Pulau Tunda masih berbentuk home stay. Wisatawan dan pemilik home stay ini pun tidak banyak. Selama ini wisatawan yang berkunjung biasanya menginap di tempat guide yang menjadi pemandunya saat berlibur di Pulau Tunda. Selain home stay sebenarnya di Pulau Tunda terdapat 2 villa dan 2 cottage. Namun pemanfaatannya tidak terlalu optimal. Villa tersebut terletak di bagian barat Pulau Tunda dan di bagian utara Pulau Tunda sedangkan cottage berada di bagian timur Pulau Tunda.

\subsection{Potensi Non-Fisik Kebudayaan}

a. Sebelum upacara adat pernikahan dilaksanakan, pada malam sebelumnya para peserta mendapat undangan berupa 3 batang rokok untuk undangan laki-laki dan 1 sachet shampo untuk undangan wanita. Para peserta ikut melakukan berbagai prosesi pernikahan adat di Pulau Tunda. Terdapat rangkaian iringiringan beserta rombongan yang mengantarkan seserahan bagi pengantin wanita. Para rombongan bergerak menuju rumah pengantin wanita bersama-sama. Setibanya di lokasi pengantin wanita berlangsung penyampaian sambutan dari berbagai pihak. Acara selanjutnya yaitu makan bersama dan kemudian pengantin wanita akan berkeliling memasuki rumah-rumah warga. Pada malam harinya dilanjutkan dengan acara resepsi pernikahan. Seusai menikmati berbagai hidangan dan hiburan dari acara pernikahan tersebut para tamu undangan diperbolehkan pulang untuk menikmati waktu istirahat di kediaman masing-masing. Nilai yang ditanamkan pada acara adat pernikahan ini adalah budaya gotong royong. Membagi bersama tanggungan yang ada sehingga menjadi ringan untuk dijalankan. Sikap saling peduli antar sesama manusia. 
b. Di Desa Wargasara, jika dilihat dari keramahtamahan masyarakat setempat, mereka sangat terbuka sekali serta menerima kehadiran orang dari luar desa tersebut. Masyarakat setempat selalu ramah dengan memberikan respone positif untuk wisatawan mancanegara maupun lokal yang sedang berwisata di Pulau Tunda. Adanya kegiatan lingkungan di Pulau Tunda membuat semangat gotong royong juga rasa saling memiliki serta kebermanfaatan bersama dapat tumbuh, begitupun pelestarian alam dan kepeduliannya.

\subsection{Analisis SWOT di Pulau Tunda}

Untuk mengkaji kondisi dan keadaan Pulau Tunda sebagai objek wisata bahari dipergunakan analisis SWOT (Strength, Weakness, Opportunities, and Thretment). Analisis ini akan melihat segi kekuatan, kelemahan, tantangan, dan peluang yang mempunyai potensi untuk dikembangkan di Pulau Tunda. Berikut ini akan disajikan hasil dari analisis tersebut.

\section{a. Kekuatan (Strenght) :}

1. Underwater Great Walls/Hanging Walls

Pulo Tunda mempunyai pesona alam bawah laut yang indah dan masih natural. Seperti terumbu karang yang dapat disebut underwater great walls merupakan tembok karang besar berbentuk vertical seperti tebing lalu menjulang tinggi keatas setinggi 10-15 meter.

2. Mangrove, Padang Lamun, dan Laguna

Pulau Tunda yang merupakan daerah pulau yang memiliki ekosistem dengan produktifitas tinggi seperti lamun dan hutan mangrove. Hutan mangrove yang tersebar di sekeliling Pulau Tunda sangatlah beragam. Hutan Bakau adalah salah satu vegetasi utama dalam mendukung kehidupan di wilayah tepi. Hutan Bakau berpotensi untuk membantu kehidupan masyarakat baik secara ekonomi, lingkungan, maupun social. Lamun merupakan vegetasi khas yang berada pada perairan dangkal. Vegetasi Allsmatales yang hidup pada air asin berfungsi sebagai sumber makanan dari biota laut, stabilisator perairan sehingga air laut jernih, habitat dan tempat berlindung untuk berbagai spesies biota laut. Sedangkan, Laguna merupakan perkumpulan air asin yang terpisahkan dari air laut oleh karang, pasir, ataupun pemisah semacamnya.

3. Kehidupan masyarakat khas pulau

Keberadaan masyarakat Pulau Tunda yang terpisah dengan Kota Serang dan hidup di suatu pulau mendorong masyarakat Desa Wargasara untuk beraktivitas cenderung lebih tradisional dengan memanfaatkan alam disekitarnya misalnya melakukan pekerjaan dengan cara yang masih cenderung tradisional.

b. Kelemahan (Weakness) :

1. Kualitas SDM Pulau Tunda

Sumber daya manusia masyarakat Desa Wargasara banyak yang masih kurang memiliki keterampilan di bidang pariwisata dan masih banyak yang berpendidikan rendah, Masyarakat yang hingga kini belum memiliki sadar wisata yang besar akan segala potensi yang dimiliki Pulau Tunda, hal ini dapat menghambat pengembangan Pulau Tunda untuk dilakukannya kegiatan pariwisata. Hal ini juga dikarenakan karena kondisi Pulau Tunda yang jauh dari pusat kota dan keterbatasannya Teknologi Informasi \& Komunikasi yang masuk.

2. Percepatan pasang dan surut laguna

Gaya grafitasi dan gaya saling tarik menarik mengakibatkan volume air laut naik dan turun secara statis. Ini merupakan suatu fenomena yang disebut pasang dan surut. Pasang-surut ini yang mengakibatkan Laguna tidak selalu ada di permukaan air setiap saat. Percepatan pasangsurut yang terjadi membuat Laguna tergenang ketika air laut pasang dan terlihat ketika air laut sedang surut yang vegetasi tumbuhan pada laguna tersebut bertoleransi pada garam.

3. Efektivitas kapal bermotor

Penggunaan kapal bermotor terlalu sering dapat mempengaruhi ekosistem dan biota laut. Perlu adanya pembatasan penggunaan kapal ataupun boat di sekitar wilayah konservasi laut Pulau Tunda. Pengalihan energi kapal bermotor menjadi eneri yang ramah lingkungan sangat diperlukan untuk menjaga kelestarian alam bawah laut Pulau Tunda.

4. Kurangnya fasilitas pendukung wisata

Fasilitas pendukung wisata di Pulau Tunda sangatlah minim. Ketersediaan lahan yang luas belum dapat dimaksimalkan dengan baik oleh masyarakat maupun pemerintah setempat. 
Kurangnya fasilitas bisa dirasakan pengunjung seperti tidak puas karena kurangnya toilet umum, tempat makan, toko oleh-oleh, maupun penginapan yang berada di sekitar tempat wisata, ATM, serta jaringan listrik yang belum menjangkau Pulau Tunda ini.

5. Sampah yang belum dikelola dengan baik

Sampah menjadi problematika utama di Pulau Tunda, karena sebagian besar kegiatan wisata yang dilakukan di pesisir Pulau Tunda dikelilingi sampah yang belum dapat dikelola dengan sangat baik. Sebagian sampah di Pulau Tunda juga merupakan kiriman dari pulau-pulau yang berada di sekeliling laut Pulau Tunda yang dibawa oleh arus angin laut.

\section{c. Peluang (Opportunities)}

1. Kebutuhan wisata yang semakin meningkat

Berwisata adalah salah satu kegiatan yang penting saat ini bagi masyarakat Indonesia. Berwisata dapat membuang rasa lelah, menambah akan pengetahuan sekitar, dan menjalin hubungan kekeluargaan secara dekat. Kegiatan wisata tidak hanya untuk kalangan atas melainkan banyaknya masyarakat kelas tengah sampai bawah yang melakukannya saat ini. Masyarakat bisa menghemat uangnya demi untuk melakukan kegiatan wisata 1-4 kali dalam 1 tahun.

2. Lokasi Pulau Tunda yang cenderung strategis

Lokasi yang dekat dengan Ibukota Indonesia yaitu Jakarta membuat pemerintah bisa memfasilitasi kapal cepat untuk jemput tamu langsung dari Jakarta. Karena jarak antara Pulau Tunda dengan Kepulauan Seribu hanya beda satu jam. Pulau Tidung dengan Pulau Tunda beda satu Jam. Pulau Tidung ke muara angke itu 3-4 jam. Sedangkan Pulau Tunda Ke Muara Angke 4 jam. Hanya saja fasilitas dari Pulau Tunda ke Pulau Seribu Belum ada jadi lebih sulit, hal ini yang membuat tamu-tamu biasanya datang ke Serang dulu kemudian menuju ke Pulau Tunda. Karena pengunjung di Pulau Tunda lebih banyak orang Jakarta dibanding orang Serang yang hanya beberapa, karena mereka datang hanya karena penasaran.

\section{Ketertarikan Investor}

Banyak potensi yang Pulau Tunda miliki dan ketersediaan lahan yang luas dapat mengundang investor luar untuk masuk dan membantu mengembangkan kegiatan pariwisata di Pulau Tunda ini.

4. Gaya hidup back to nature sedang marak

Kecenderungan masyarakat dunia dalam gerakan "back to nature" menjadi pendukung berkembangnya wisata bahari. Selain itu juga lokasi Pulau Tunda yang dekat dengan Jakarta sebagai Ibukota Indonesia yang dikenal dengan aktivitas perkotaannya membuat masyarakatnya jauh dari kehidupan tradisional. Hal ini menjadi peluang Pulau Tunda untuk menjaring wisatawan jenis ini.

\section{d. Ancaman (Threats)}

1. Kapal Penambang Pasir

Di sekeliling Pulau Tunda (ke arah laut dalam) terdapat kegiatan penambangan pasir laut dan tidak jauh dari Pulau Tunda juga terdapat kegiatan transportasi laut yang didominasi oleh aktifitas pelayaran kapal ferry dan perahu nelayan yang berukuran cukup besar. Kegiatan dengan tingkat pemanfaatan sumberdaya (pasir) yang sangat intensif tersebut sangat mengkhawatirkan keberadaan wilayah Pulau Tunda dan ekosistem baharinya yang bersifat sangat fragile.

2. Kurangnya perhatian dari pemerintah daerah

Kurangnya perhatian dari pemerintah daerah dikarenakan adanya kesenjangan antara masyarakat terhadap pemerintah desa maupun pemerintah daerah yang diakibatkan karena adanya dinamika politik yang membuat pemerintah desa khususnya kepala desa tidak welcome dengan masyarakat P.Tunda, hanya welcome dengan orang-orang disekitarnya. Sedangkan dari pemerintah daerah itu sendiri dikarenakan keterbatasan anggaran serta ketidaksingkronan pemerintah daerah dengan masyarakat Pulau Tunda mengenai apa yang sedang dibutuhkan Pulau Tunda itu sendiri.

3. Eksploitasi menangkap ikan

Ekploitasi menangkap ikan adalah salah satu tindakan yang illegal yang dapat mengancam tingkat populasi ikan di wilayah tersebut. Akibatnya eksploitasi menangkap ikan secara langsung akan mempengaruhi keseimbangan ekosistem dan secara tidak langsung akan membuat kesejahteraan nelayan local menurun sehingga berganti pekerjaan.

4. Perkembangan wisata yang serupa 
Perkembangan wisata serupa yang lebih siap dari Pulau Tunda. Pulau Tunda harus mempunyai daya tarik khusus dan icon yang menjadi identitas utama, sehingga Pulau Tunda dikenal oleh banyak orang dan tidak bergantung dengan pasar wisata yang saat ini sedang berkembang juga.

\subsection{Strategi Pengembangan Potensi Bahari Pulau Tunda}

Berdasarkan analisis SWOT di atas menghasilkan strategy yang dilakukan untuk mengembangkan potensi wisata di Pulau Tunda pada opportunities dan threat diluar yang akan dieliminasi oleh strenght dan juga weakness didalam dipunyai oleh Pulau Tunda seperti berikut :

\subsubsection{Strategy (SO)}

a. Melakukan Transplantasi dan Konservasi Terumbu Karang melalui kegiatan penanaman terumbu karang buatan ataupun dengan melalui kegiatan wisata agar dapat menunjang keberlangsungan ekosistem bawah laut Pulau Tunda untuk kedepannya.

b. Ketidakadaan icon Pulau Tunda dengan landmark Wisata Bahari itu sendiri membuat Pulau Tunda tidak optimal dalam promosinya, sehingga dengan menjadikan Underwater Great Walls atau Hanging Walls sebagai icon Pulau Tunda itu sendiri bisa menambah kekuatan branding wisata bahari di Pulau tersebut.

c. Memaksimalkan dan membuat spot untuk aktivitas Watersport Canoe di sekitar kawasan Utara sampai Tanjungan Timur Pulau Tunda.

d. Menjadikan aktivitas kehidupan khas masyarakat pulau seperti memancing gurita menjadi sebuah atraksi wisata/edukasi untuk wisatawan, salah satunya seperti memancing gurita dengan cara tradisional yang terkesan unik dan menarik.

\subsubsection{Strategy (ST)}

a. Membuat Kebijakan maupun Regulasi yang tegas terhadap kegiatan penambang pasir yang dilakukan disekitaran laut Pulau Tunda yang berjarak 2 mil dari Pulau Tunda.

b. Bantuan pemerintah untuk pembuatan sertifikat/license pendukung pariwisata seperti sertifikat guide/diver/home stay yang dimaksudkan agar pelaku wisata di Pulau Tunda memiliki kredibilitas yang tinggi sehingga dapat meningkat kepercayaan wisatawan kepada pelaku wisatawan objek wisata di Pulau Tunda.

\subsubsection{Strategi Wo}

a. Menggerakkan kegiatan pembersihan pantai untuk melestarikan lingkungan pantai di Pulo Tunda maupun konservasi alam bawah laut Pulau Tunda yang merupakan kawasan konservasi perairan di Kabupaten Serang.

b. Pembangunan fasilitas maupun sarana dan prasarana umum sebagai pendukung wisata berupa toilet, tempat duduk, gazebo, tempat makan dan lainnya agar wisata terlihat lebih teratur, rapi, bersih sehingga wisatawan memiliki kegiatan lain selain kegiatan snorkeling seperti saat ini.

c. Melakukan pemberdayaan masyarakat seperti melakukan pembinaan masyarakat menjadi pemandu wisata serta wawasan kepariwisataan bagi penduduk lokal. Pelatihan perlu dilakukan agar penduduk lokal dapat terserap bekerja di bidang pariwisata secara merata ataupun membuat usaha kepariwisataan secara mandiri sehingga seluruh masyarakat Pulau Tunda terlibat dan mendapatkan keuntungan dari kegiatan wisata yang ada.

\subsubsection{Strategi WT}

a. Pendampingan pemerintah dalam proses pengembangan Pulau Tunda. Pendampingan ini perlu dilakukan karena pemerintah sebagai pemegang 
kebijakan tertinggi. Wewenang yang dimiliki pemerintah dalam membuat kebijakan yang strategis dan berdampak positif bagi pengembangan Pulau Tunda diperlukan untuk menekan hambatanhambatan yang mungkin terjadi pada pengembangan Pulau Tunda.

\section{PENUTUP}

\subsection{Simpulan}

Dari Strategy dalam mengembangkan potensi wisata khsusnya wisata bahari di Pulau Tunda yang dianalisis menggunakan SWOT (Strenght, Weakness, Opportunities, Threats) memperoleh hasil berupa potensi untuk dikembangkan dan strategy untuk mengembangkan daya tarik wisata bahari pada Pulau Tunda dengan mengoptimalkan kelestarian juga pemanfaatan potensi. Hambatan berupa kendala yang dapat menghambat pengembangan potensi data tarik wisatanya. Begitupun diperlukan kebijaksanaan dalam pemecahan yang terjadi di lapangan mengenai pengembangan Pulau Tunda.

\subsection{Saran}

Meningkatkan fasilitas dan aksesbilitas agar wisatawan yang datang berkunjung lebih mudah untuk berwisata sekaligus mendapatkan kepuasan dan pengalaman lebih dari Pulau Tunda.

Menambah dan mengatur kelembagan Desa Wargasara agar lebih mudah dan terarah terhadap pengembangan Pulau Tunda ke depannya sehingga kesejahteraan dapat dirasakan secara merata.

Pemerintah desa hendaknya melibatkan masyarakat setempat yaitu warga desa wargasara dalam kegiatan pariwisata seutuhnya di Pulau Tunda sehingga aspirasi masyarakat dapat terwujud. Membantu pengembangan objek wisata dalam menjaga kelestarian alam, namun tetap dibina dan diawasi oleh Pemerintah Daerah Kabupaten Serang.

Melakukan pembinaan dan pelatihan terhadap masyarakat setempat mengenai hal-hal yang berkaitan dengan kegiatan pariwisata, serta menambah wawasan dan kepedulian masyarakat akan kekayaan alam Pulau Tunda.
Pembuatan zonasi-zonasi kegiatan wisata dan kebijakan yang tegas terhadap kegiatan yang dapat mengancam ekosistem di dalam pulau maupun di luar Pulau Tunda.

\section{DAFTAR PUSTAKA}

Republik Indonesia. 2010. Undang-Undang tentang kepariwisataan

Chamdani, U. 2018. Pengembangan Wisata Bahari Yang Berkelanjutan. Yogyakarta : Deepublish

Collins, J.H. 2008. Kimberly Region Marine Tourism in Western Australia

Darmajati. 2001. Tinjauan tentang potensi: Potensi wisata fisik dan non fisik.

Fandeli, C. 1995. Potensi Obyek Wisata Alam Indonesia

Marrioti. 1983. (DalamYoeti 1983: 160-162) Pengetian Tentang Potensi.

Laporan Akhir Kajian Pengelolaan Ekosistem Pulau Tunda untuk Pengembangan Minawisata Tahun 2015. Dinas Kelautan, Perikanan, Energi dan Sumberdaya Minera Kabupaten Serang

Laporan Kemajuan Kajian Potensi Sumberdaya Alam dan Lingkungan Pesisir Pulau Tunda Untuk Perencanaan Ekowisata Bahari Yang Berkelajutan Tahun 2015. Kerjasama Dinas Kelautan, Perikanan, Energi dan Sumberdaya Mineral Kabupaten Serang dengan LPPM IPB

Mukthar. 2013. Pengertian Tentang Purposive Sampling.

Nurmawati. 2012. Pengembangan Pariwisata Untuk Mengembangkan Potensi Lokal.

Paturusi. S. A. 2001. Tata Ruang Pariwisata dalam Perencanaan. Denpasar : Universitas Udayana

Rangkuti, F. 2002. Analisis SWOT Membedah Kasus Bisnis. GramediaPustaka Utama ; Jakarta

RPJMD Dinas Pariwisata dan Budaya Provinsi Banten Tahun 2012-2017

RPJMD Kab.Serang Tahun 2010-2015

RZWP3K Kabupaten Serang 2013-2033

Sastrawan. I G.A. 2014. Strategy Mengembangkan Potensi Wisata Bahari Pantai Crystal Bay Desa Sakti, Kecamatan Nusa Penida, Kabupaten Klungkung

Sugiyono. 2008. Metode Penelitian R\&D, Kualitatif, dan Kualitatif dan R\&D. Bandung : Alfabeta

Selayang Pandang Pariwisata, Pemuda, juga Olahraga Kabupaten Serang. Dinas Olahraga dan Pariwisata Kabupaten Serang

Sumber lainnya :

https://www.kompasiana.com/nawawimnoer/5ab89b56dd 0fa868be7e2612/sosial-ekonomi-masyarakatpesisir/ (diakses pada tanggal 15 November 2018)

http://cvinspireconsulting.com/konsep-pengembanganpariwisata/ (diakses pada tanggal 15 November 2018) 